Jpn. J. Toxicol. Environ. Health

徫 ${ }^{43}$ (2) 生 $129-139$ 化

農作物中 9 種フェノキシ酸系除草剤分析のためのメチル化及びペンタ フルオロベンジル化の比較

\author{
平原嘉親, ${ }^{a}$ 宮田昌弘, ${ }^{a}$ 鎌倉和政, ${ }^{a}$ 渡辺芳則, ${ }^{a}$ \\ 武田 寿, $b$ 前田憲二, $b$ 外海泰秀, $*, c$ \\ 神戸検疫所輸入食品検疫 ·検查センター, ${ }^{a}$ 横浜検疫所輸入食品検疫 $\cdot$ 検查センター, ${ }^{b}$ 国立 \\ 衛生試験所大阪支所 ${ }^{c}$
}

\title{
Comparison between Methyl and Pentafluorobenzyl Esterification for Analysis of 9 Phenoxy Acid Herbicides in Agricultural Products
}

\author{
Yoshichika Hirahara, ${ }^{a}$ Masahiro Miyata, ${ }^{a}$ Kazumasa Kamakura, ${ }^{a}$ Yoshinori Watanabe, \\ Hisashi TAKedA, ${ }^{b}$ Kenji MAEdA, ${ }^{b}$ and Yasuhide TonogaI, ${ }^{*, c}$ \\ Kobe Quarantine Station, Center for Inspection of Imported Foods and Infectious Diseases, ${ }^{a}$ 1-1 \\ Toyahama-cho, Hyogo-ku, Kobe 652, Japan, Yokohama Quarantine Station, Center for \\ Inspection of Imported Foods and Infectious Diseases, ${ }^{b}$ 107-8 Nagahama, \\ Kanazawa-ku, Yokohama 236, Japan and National Institute of Health \\ Sciences, Osaka Branch, ${ }^{c}$ 1-1-43 Hoenzaka, Chuo-ku, \\ Osaka 540, Japan
}

(Received August 12, 1996)

Ester types (2,4-dichlorophenoxyacetic acid (2,4-D) ethyl, 2,4-D butyl and MCPA-thioethyl) and free acid types (2,4-D, 2,4,5-trichlorophenoxyacetic acid (2,4,5-T), 2-methyl-4-chlorophenoxyacetic acid (MCPA), $m$-chloroperbenzoic acid (MCPB), mecoprop and dichlorprop) of phenoxy acid herbicides in agricultural products were simultaneously extracted from samples with acetone for vegetables/fruits, and with acetonitrile for cereals/beans, and then re-extracted with ethyl acetate.

Three ester types of herbicides extracted from the samples were cleaned up by Sep-Pak ${ }^{\circledR}$ Florisil, and then determined by ECD-GC and GC-MS (SIM). Recoveries of the ester types of herbicides determined by GC and GC-MS spiked at 1.25 ppm to asparagus, taro, brown rice and corn were $61.4-76.9 \%$ and $50.8-63.9 \%$, respectively.

Six free acid types of herbicides were esterified by pentafluorobenzyl bromide or diazomethane and determined by GC-MS (SIM) without cleaning up by solid phase extraction. Recoveries of the free acid types of herbicides esterified by pentafluorobenzylation and methylation spiked at $1.25 \mathrm{ppm}$ to the samples were $68.5-98.5 \%$ and $53.7-88.1 \%$, respectively.

It was clarified that the concentration of pentafluorobenzyl bromide in acetone should be 5 $10 \%$ to have sufficient recoveries for the esterification. Methylation was superior to pentafluorobenzylation for the simplicity of manipulation, but was inferior for the sensitivity of GC and GC-MS.

Key words — pesticide ; phenoxy acid herbicide; Sep-Pak ${ }^{\circledR}$ Florisil ; gas chromatography; gas chromatograph/mass spectrometer; selected ion monitor (SIM) 


\section{緒言}

フェノキシ酸系農薬は水田・畑地等の除草剂とし て広く使用されており，2,4-dichlorophenoxyacetic acid (2, 4-D), ジクロルプロップ, 2, 4, 5-trichlorophenoxyacetic acid (2, 4, 5-T), 2-methyl-4-chlorophenoxyacetic acid (MCPA), $m$-chlorobenzoic $\operatorname{acid}(\mathrm{MCPB}) ， メ コ フ ゚ ロ ッ フ ゚$ 等の遊離カルボン酸を 持つものと，それらの塩及び 2, 4-Dのエチル，ブチ ルエステルや MCPAのチオエチルエステル（フェ ノチオール）等のエステル体がある.

現在環境庁の登録保留基準1) では 2, 4-D エチル, 2, 4-Dジメチルアミン，2, 4-D ナトリウムは米に

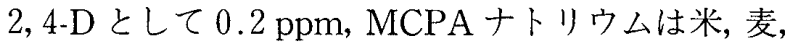
雑穀，芋類に $0.1 \mathrm{ppm}, \mathrm{MCPB}$ エチルは米に 0.1 $\mathrm{ppm}$, 果実に $0.2 \mathrm{ppm}$, ジクロルプロップは果実に $3 \mathrm{ppm}$ と定められている。 また厚生省の農作物中農 薬の残留基準では 2, 4, 5-T は各種農作物について 検出されてはならないと定められている。

一方，米国では 2, 4-D は除草剂としてのほかに， レモン等柑橘類の収穫後の品質保持を目的として, いわゆるポストハーベスト農薬としての使用が認め られており，2）残留基集は柑橘類について $5 \mathrm{ppm}$ と 定められている. 平成 2 年頃, 米国より日本一輸大 されたレモンから 2, 4-Dやイマザリルが検出され, 話題になった。
フェノキシ酸系除草剤の多成分分析は主として水 や土猿試料についての報告 ${ }^{3-6)}$ が多く，農作物につ いての報告6,7) は比較的少ない. 測定法としては高速 液体クロマトグラフィー $(\mathrm{HPLC})^{8-10)}$ が多く, つい でガスクロマトグラフィー $(\mathrm{GC})^{11-13)}$ があり，がス クロマトグラフ-質量分析計 (GC-MS) ${ }^{14,15)}$ や液体ク ロマトグラフ-質量分析計 (LC-MS) ${ }^{16,17)}$ で測定した 報告も見られる。

フェノキシ酸系農薬の GC 分析では, 遊離酸型の ものは不揮発性であるため, 何らかのエステル化体 にする必要がある、エステル化にはメチルエステ ル, ${ }^{4,18)} n$-ブチルエステル, ${ }^{4,19)}$ ペンタフルオロベン ジルエステル, ${ }^{13,20,21)} 2,2$, 2-トリフルオロエチルエ ステル22)などが報告されている。

本報告では Fig. 1 に示した遊離酸型及びエステ ル型フェノキシ酸系 9 種除草剂の同時抽出並びに一 斉分析法の設定を目的とした。遊離酸型はジアゾメ タンによるメチルエステル化並びにペンタフルオロ ベンジル化（PBF化）について比較し，エステル化 後選択イオン検出 (SIM) 法による GC-MS で直接測 定する方法について検討した。またエステル型につ いては，ECD-GC と GC-MS (SIM) 法を比較検討し た.

\section{実 験 の 部}

1. 試料オーストラリア産のアスパラガス,<smiles>O=C(O)COc1ccc(Cl)cc1Cl</smiles>

$2,4-D(2,4-P A)$<smiles>CC(Oc1ccc(Cl)cc1Cl)C(=O)O</smiles>

Dichlorprop<smiles>O=C(O)COc1cc(Cl)c(Cl)cc1Cl</smiles>
$2,4,5-\mathrm{T}$<smiles>Cc1cc(Cl)ccc1OCC(=O)O</smiles>

MCPA (MCP)<smiles>Cc1cc(Cl)ccc1OCCCCCCC(=O)O</smiles>

$\mathrm{MCPB}$<smiles>Cc1cc(Cl)ccc1OC(C)C(=O)O</smiles>

Mecoprop (MCPP)<smiles>CCCCCCC(=O)COc1ccc(Cl)cc1Cl</smiles>

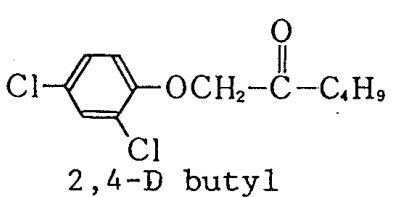

2,4-D buty 1<smiles>CCCCCCC(=O)COc1ccc(Cl)cc1C</smiles>

MCPA-thioethyl(Fenothiol)

Fig. 1. Chemical Structures of Phenoxy Herbicides 
中国産のさといも，U.S.A. 産のとうもろこし及びう るち玄米を用いた。

2. 試薬及び試液 農薬標準品: $2,4-\mathrm{D}$, MCPA は和光純薬工業（株）製，2, 4, 5-T，ジク口

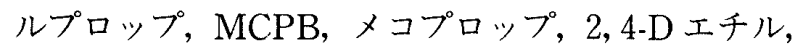
2, 4-D ブチル, MCPA-チオエチル(フェノチオール) は林純薬工業（株）製を用いた。

農薬標準混合溶液：エステル型フェノキシ酸系農 薬混液 A（2，4-D エチル，2４-D ブチル，MCPA-チ オエチル）及び遊離酸型フェノキシ酸系農薬混液 $\mathrm{B}$ (2, 4-D, 2, 4, 5-T, ジクロルプロップ, MCPA, $\mathrm{MCPB}$, メコプロップ)をそれぞれ $25 \mu \mathrm{g} / \mathrm{ml}$ の濃度 になるようにアセトンで調製した。

塩酸, 炭酸カリウム, 水酸化カリウム: 和光純薬 工業（株）製，特級。

臭化ペンタフルオロベンジル：関東化学 (株) 製. $N$ メメチル $N$-ニトロソ尿素：ナカライテスク

（株）製.

$\mathrm{PBF}$ 試液：臭化ペンタフルオロベンジルのアセ トン溶液 $(10 \% \mathrm{w} / \mathrm{v})$ を作製した。

ジアゾメタン試液： $N$-メチル $N$-ニトロソ尿素 $3 \mathrm{~g}$ 及び $40 \%$ 水酸化カリウム溶液 $9 \mathrm{ml}$ をジエチル エーテル $30 \mathrm{ml}$ に冷却下で混和して作製した。

アセトン, ジエチルエーテル, $n$-ヘキサン, 酶酸 エチル，アセトニトリル：和光純薬工業（株）製， 残留農薬試験用。

Sep-Pak ${ }^{\circledR}$ フロリジル：Waters 社製, プラス型.

3. 装置及び測定条件ガスクロマトグラフ： ヒューレットパッカード社製, $5890 \mathrm{II}$, 電子捕獲型検 出器 (ECD) 付き.

$\mathrm{GC}$ 条件——ラム：DB-1701，J\&W Scientific 社製，（内径 $0.25 \mathrm{~mm}$, 長已 $30 \mathrm{~m}$, 膜厚 0.25 $\mu \mathrm{m})$, 力ラム温度 : $60^{\circ} \mathrm{C}(2 \mathrm{~min})-250^{\circ} \mathrm{C}\left(5^{\circ} \mathrm{C} / \mathrm{min}\right)$, 注入口及び検出器温度: $250^{\circ} \mathrm{C}$ 及び $280^{\circ} \mathrm{C}$, 注入量 : $2 \mu 1$ (スプリットレス)，キャリアーガス及びメイク アップガス：ヘリウム。

GC-MS：ヒューレットパッカード社 製，5971 Series II.

GC-MS 条件——カラム：DB-1701，J \& W Scientific 社製（内径 $0.25 \mathrm{~mm}$, 長さ $30 \mathrm{~m}$, 膜厚 0.25 $\mu \mathrm{m})$, 力ラ $么$ 温度 : $60^{\circ} \mathrm{C}(2 \mathrm{~min})-250^{\circ} \mathrm{C}\left(20^{\circ} \mathrm{C} /\right.$ $\mathrm{min})$, 注入口及びイオン源温度 : $250^{\circ} \mathrm{C}$, インター フェース温度： $280^{\circ} \mathrm{C}$ ，イオン化電圧： $70 \mathrm{eV} ，$ イオ ン化方法：電子衝撃（EI）法，スキャン範囲： $50-600 \mathrm{~m} / \mathrm{z}$, 注入量: $2 \mu \mathrm{l}$ (スプリットレス), キャ リアーガス及びメイクアップガス：へリウム。

\section{4. 分析操作法}

1）試料液の調製——アスパラガス，さといも： 細切してミキサーで均一化した試料 $20 \mathrm{~g}$ をブレン ダーカップにとり，6 $\mathrm{N}$ 塩酸 $5 \mathrm{ml}$ 及びアセトン 80 $\mathrm{ml}$ を加之, 3 分間ホモジナイズし, No. 5Aのろ紙を 用いてろ過した．残留物にアセトン $80 \mathrm{ml}$ を加之同 様に抽出し，アセトン抽出液を合わせ，減圧濃縮し て約 $20 \mathrm{ml}$ とした。これに, 飽和食塩水及び酢酸工千 ルをそれぞれ $100 \mathrm{ml}$ 加え 5 分間振り混ぜた後, 有機 層を分取した. 水層に酶酸エチル $100 \mathrm{ml}$ を加之，同 様の操作を繰り返した，有機層を合わせ無水硫酸十 トリウムで脱水後, 減圧下で溶媒を留去した。残留 物をアセトン $5 \mathrm{ml}$ に溶解し, 試料液とした。

とうもろこし，玄米： $420 \mu \mathrm{m}$ の標準網子るいを 通るように粉砕した試料 $20 \mathrm{~g}$ をブレンダーカップ にとり，水 $40 \mathrm{ml}$ を加之， 2 時間放置した後， $6 \mathrm{~N}$ 塩 酸 $5 \mathrm{ml}$ 及びアセトニトリル $80 \mathrm{ml}$ を加え， 3 分間ホ モジナイズし, No.5Aのろ紙を用いてろ過した. 残 留物にアセトニトリル $80 \mathrm{ml}$ を加之同様に抽出し た。アセトニトリル抽出液を合わせ，アセトニトリ ル飽和 $n$-ヘキサン $30 \mathrm{ml}$ を加え 5 分間振り混ぜた 後,アセトニトリル層を分取した. 次に減圧濃縮し, 約 $20 \mathrm{ml}$ とした。これに, 飽和食塩水及び酢酸エチル をそれぞれ $100 \mathrm{ml}$ 加え 5 分間振り混ぜた後, 有機層 を分取した. 水層に酢酸エチル $100 \mathrm{ml}$ を加之, 同様 の操作を繰り返した．有機層を合わせ無水硫酸ナト リウムで脱水後，減圧下で溶媒を留去した。残留物 をアセトン $5 \mathrm{ml}$ に溶解し, 試料液とした。

2）フェノキシ酸系 A（エステル型）農薬のク リーンアップーー1）で調製した試料液の $1 \mathrm{ml}$ をと ク, 窒素ガス気流下で溶媒を留去した後, $n$-へキサ ン $2 \mathrm{ml}$ に溶解し, Sep-Pak ${ }^{\circledR} フ$ ロリジルカートリッ ジに負荷した。ついで $n$-へキサン $5 \mathrm{ml}$ で洗浄した 後, $10 \%$ 酢酸エチル含有 $n$-ヘキサン $(\mathrm{EA} / \mathrm{H}) 5 \mathrm{ml}$ で溶出した. 溶出液を濃縮し,アセトンで $1 \mathrm{ml}$ とし, GC または GC-MS 用の試験溶液とした。

3）フェノキシ酸系 B (遊離酸型) 農薬のエステ 儿化

3-1） PFB 化：1）で調製した試料液の $2 \mathrm{ml}$ をと ク, 窒素がス気流下で溶媒を留去した後，30\%炭酸 カリウム溶液 $0.1 \mathrm{ml}$ 及び PBF 試液 $1 \mathrm{ml}$ を加之, 密 栓後， $50^{\circ} \mathrm{C}$ の水浴中で 1 時間加温した。これに飽和 食塩水 $2 \mathrm{ml}$ 及び $n$-ヘキサン $2 \mathrm{ml}$ を加之， 2 分間振 り混ぜた後， $n$-ヘキサン層を分取した。水層に同様 に $n$-へキサン $2 \mathrm{ml}$ を加之, 振り混ぜた後, $n$-へキサ ン抽出液を合わせた。窒素がス気流下で溶媒を留去 
した後，アセトンで $2 \mathrm{ml}$ とし， GC 及び GC-MS 用

の $\mathrm{PFB}$ 化試験溶液とした。

3-2）メチル化：1）で調製した試料液 $2 \mathrm{ml}$ をと り，窒素ガス気流下で溶媒を留去した後，ジアゾメ タン試液 $10 \mathrm{ml}$ を加之, 室温で 30 分間放置した. 減 圧下で溶媒を留去した後, アセトンで $2 \mathrm{ml}$ とし, GC 及び GC-MS 用のメチル化試験溶液とした。

5. 定性, 定量 4. で調製した試駼溶液 $2 \mu 1$ を GC または GC-MSに注入し, 各種農薬を定性, 定量 した。フェノキシ酸系 B (遊離酸型) 農薬について は, 標品についてもエステル化した後, 定性, 定量 に使用した。

\section{結 果 及び考 察}

\section{1. 抽出溶媒の検討}

穀類，豆類は野菜，果実類に比べ脂肪分が多いた め，野菜，果実類と同様にアセトンで抽出すると脂 肪分が多く抽出されることから, 水で膨潤させた後, アセトニトリルで抽出した。さらに，この抽出液を アセトニトリル飽和 $n$-ヘキサンで洗浄して脱脂を 行った。登録保留基準の分析法では再抽出溶媒とし
てジクロルプロップ, MCPA, MCPB の項ではエー テルを，2４，5-Tの項では酢酸エチルを用いている。 本報ではこれら農薬の同時抽出を目的としたので, エーテルと酢酸エチルによる各農薬の回収率を比較 した。その結果，両溶媒に差はなく良好な回収率が 得られたことから, 再抽出溶媒としてはエーテルに 比べて取り扱い易く，水分の混入も少ないと考えら れる酢酸エチルを使用することとした。

2. フェノキシ酸系 $\mathrm{A}$ (エステル型) 農薬の試験法 2-1. ガスクロマトグラフィー キャピラリー カラムを用いてフェノキシ酸系 A 農薬を ECD-GC で測定したところ，3種のフェノキシ酸系 $\mathrm{A}$ 農薬は ECD-GC で感度, 分離とも良好に測定できた. 2, 4-D エチルと2,4-D ブチルは同等の感度であったが, MCPA-チオエチルはこれらの 2 倍以上の感度が得 られた。この理由は分子中にチオエーテル基を含む ため，ECD-GCにおける感度が増したためと考えら れる. 検出限界は前二者が $0.5 \mu \mathrm{g} / \mathrm{ml}$ ，後者が 0.25 $\mu \mathrm{g} / \mathrm{ml}$ であった。

2-2. 固相抽出カートリッジによるクリーンアッ プ 試料液を直接 $\mathrm{GC}$ で測定すると各農作物にお
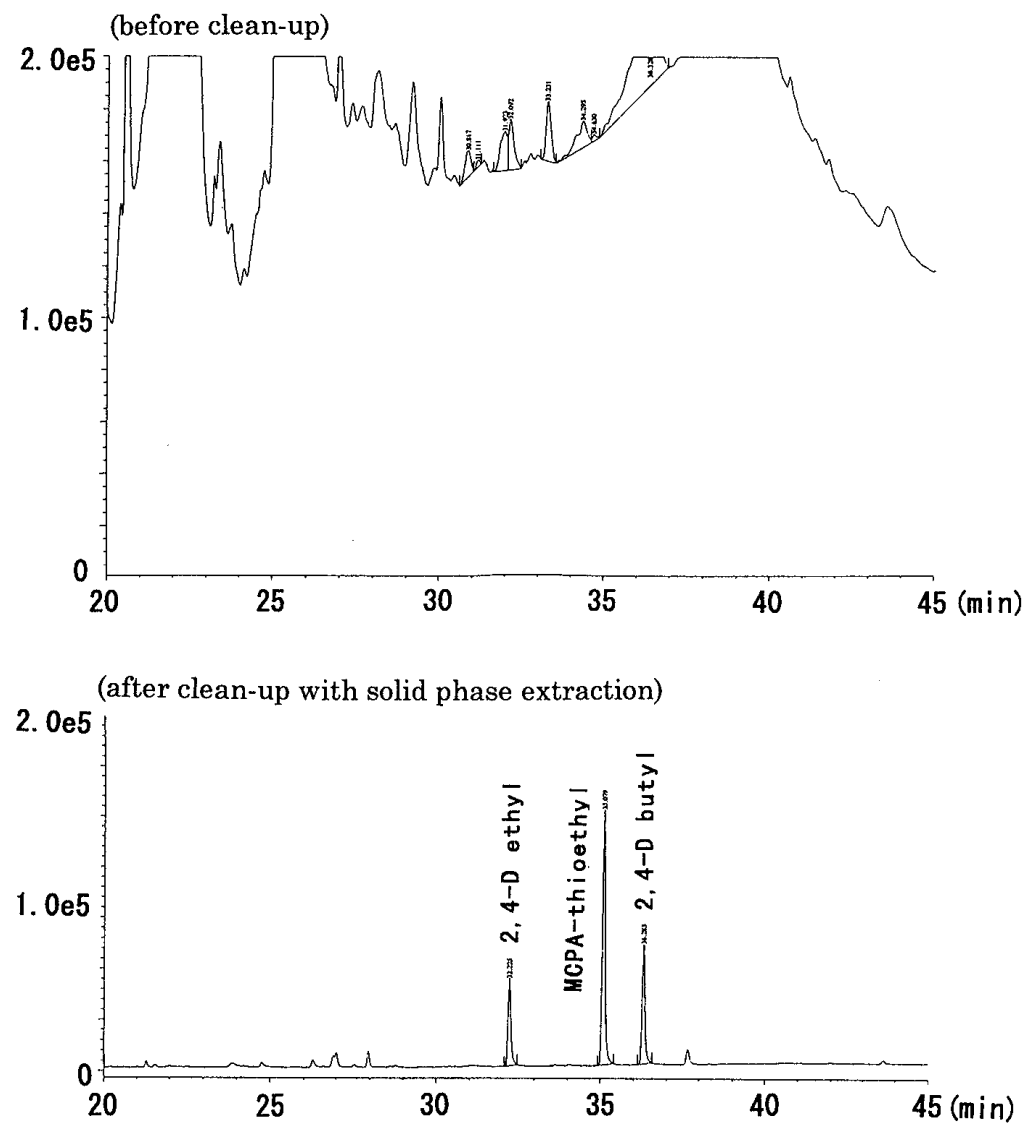

Fig. 2. Gas Chromatograms of Asparagus Extract Spiked with Pesticides (MixtureA) before and after Solid Phase Extraction by ECD-GC 
いて試料由来の妨害ピークが多く認められ，目的農 薬の保持時間と重なるため，クリーンアップが必要

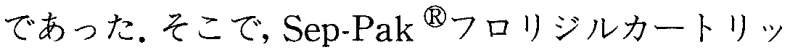
ジを用い，溶出条件の検討を行ったところ，A 農薬 は $n$-へキサン負荷液及び $5 \mathrm{ml}$ の $n$-ヘキサン洗浄液 では溶出せず，EA/H で全て溶出した。この結果か ら, $\mathrm{A}$ 農薬のクリーンアップは $n$-ヘキサンでカート リッジに負荷した後, $5 \mathrm{ml}$ の $n$-へキサンで洗浄し, $10 \% \mathrm{EA} / \mathrm{H} 5 \mathrm{ml}$ で溶出することとした.

各農作物の試料液に農薬を $1.25 \mathrm{ppm}$ となるよう に添加し，フロリジルカートリッジでクリーンアッ プし，ECD-GCで測定した結果，試料由来の妨害 ピークは除去され，良好に测定することができた。

また各農作物に農薬を添加したときも同様であっ た.アスパラガスについてのガスクロマトグラムを Fig. 2 に示した。

2-3. GC 及 び GC-MS（SIM）による測定 フェノキシ酸系A 農薬を GC-MSの全イオン検出 (TIC) 法で測定したところ，良好な分離と感度が得 られた。またこれらのマススペクトルでは，各農薬 の分子イオンピークを認めた. 2, 4-D工チルは $\mathrm{m} /$ $z 248,2,4-\mathrm{D}$ ブチルは $m / z 276, \mathrm{MCPA}$-チオエチル は $m / z 244$ の分子イオンピークをモニターイオン として SIM 法で各農薬を測定した結果, 良好な分離 及び感度が得られた。

\section{2-4. 添加回収試験 フェノキシ酸系 $\mathrm{A}$ 農薬} を各農作物に $1.25 \mathrm{ppm}$ となるように添加し, GC 及 U゙ GC-MS (SIM) で測定して添加回収率を求め，そ の結果を Table 1 に示した。 またアスパラガスにつ いての GC-MS (SIM)によるクロマトグラムを Fig. 3 に示した。 すべての農作物において農薬の保持時 間に試料由来の妨害ピークは重ならず，良好に測定 することができた。

各農作物における添加回収率はGCでは61.4一 76.9\%，また GC-MS（SIM）では50.8一63.9\%で
あった，GCに比べ GC-MS で測定した添加回収率 は約 10\%低かったが，GC-MSではピークとして表 われない共存物の影響を受けることも少なく，感度 の変動も小さいので，より信頼できる値と考えられ る。また，各農作物間，各農薬間で回収率に大きな 差は認められなかった。

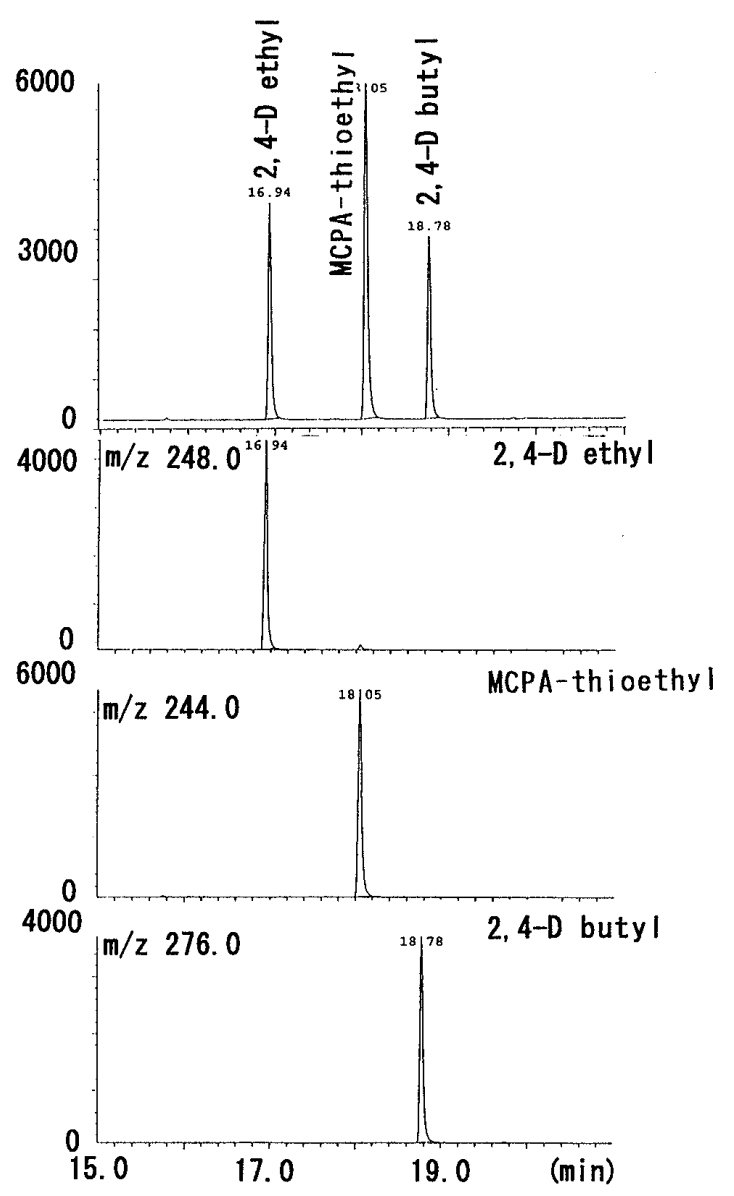

Fig. 3. TIC and Mass Chromatograms of Asparagus Extract Spiked with Pesticides (Mixture A)

Table 1. Recoveries of Phenoxy Acid Herbicides (Mixture A) from Spiked Agricultural Products by ECD-GC and GC-MS (SIM)

\begin{tabular}{llcccc}
\hline \hline \multirow{2}{*}{$\begin{array}{c}\text { Pesticide }^{a)} \\
\text { (mixture A) }\end{array}$} & & \multicolumn{4}{c}{ Recovery (\%, mean \pm S.D., $n=8)$} \\
\cline { 3 - 6 } 2,4-D ethyl & ECD-GC & $69.0 \pm 2.3$ & $61.4 \pm 3.1$ & $74.2 \pm 3.2$ & $64.3 \pm 2.2$ \\
& GC-MS (SIM) & $55.2 \pm 3.1$ & $50.8 \pm 2.5$ & $61.4 \pm 2.8$ & $57.5 \pm 2.6$ \\
MCPA-thioethyl & ECD-GC & $71.8 \pm 1.8$ & $65.8 \pm 1.8$ & $69.8 \pm 2.7$ & $67.2 \pm 1.5$ \\
& GC-MS (SIM) & $56.8 \pm 2.6$ & $55.7 \pm 2.3$ & $52.3 \pm 1.7$ & $56.2 \pm 2.8$ \\
2,4-D butyl & ECD-GC & $76.9 \pm 2.2$ & $67.4 \pm 1.9$ & $72.4 \pm 2.3$ & $68.0 \pm 2.3$ \\
& GC-MS (SIM) & $61.2 \pm 3.5$ & $57.1 \pm 1.6$ & $63.9 \pm 2.9$ & $63.4 \pm 3.4$ \\
\hline
\end{tabular}

a) Twenty five $\mu \mathrm{g}$ of phenoxy acid herbicides (mixture A) were spiked to $20 \mathrm{~g}$ of each agricultural products. 
3. フェノキシ酸系 $\mathrm{B}$ (遊離酸型) 農薬の試験法

3-1. $\mathrm{GC}$ 条件の検討 フェノキシ酸系 $\mathrm{B}$ 農薬 の誘導体化には登録保留基準の MCPA, MCPB 分 析法に使用されている臭化ペンタフルオロベンジル を用いる PFB 化と各種化合物の分析に利用されて いるジアゾメタンを用いるメチル化の 2 種のエステ ル化について検討した。

PFB 化した各農薬を ECD-GC で測定した結果, フェノキシ酸系 B 農薬のすべてを検出することが できた。しかしメチル化の場合，2，4-D，2，4，5-T 及 びジクロルプロップのピークは検出できたが MCPA， MCPB及びメコプロップのピークは検出 できなかった，2４-D，2４，5-T 及びジクロルプロッ プは分子中に塩素原子を 2-3 個持つが, MCPA, MCPB 及びメコプロップは 1 個しか持たないため, ECD-GCでの感度の低いことが原因と考えられる。 一方, $\mathrm{PFB}$ 化ではフッ素原子を 5 個導入することに より, すべての農薬がメチル化に比べ, ECD-GCで 高感度に検出された。

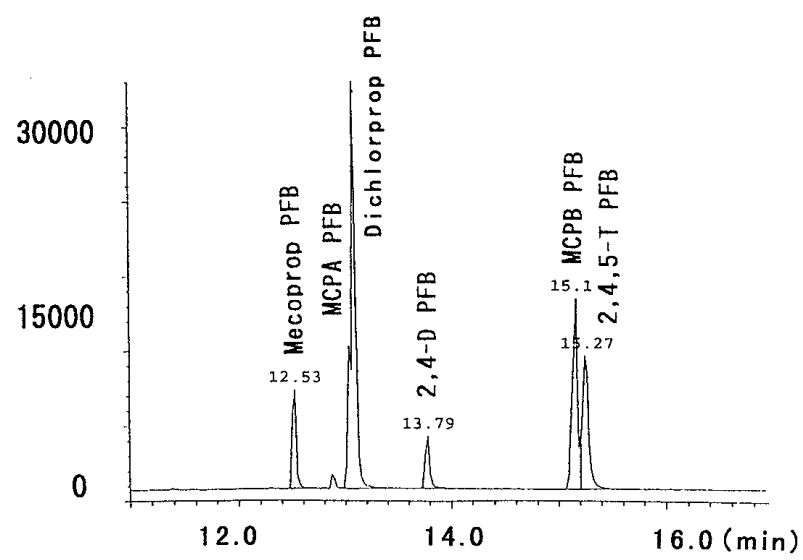

Fig. 4. TIC for Pentafluorobenzyl Derivatives of Phenoxy Acid Herbicides (Mixture B : $5.0 \mu \mathrm{g} / \mathrm{ml}$ )
しかし, PFB 化の試薬ブランクピークはメチル化 のそれに比べ大きかった。さらに，この試薬ブラン

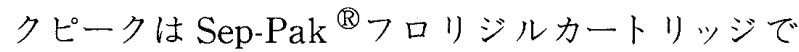
精製しても除去できなかった。このことから，PFB 体を GCで測定する場合, $0.5 \mu \mathrm{g} / \mathrm{ml}$ 以下では試薬 ブランクピークと重なり定量が困難であった。

3-2. GC-MS 条件の検討 前述した理由によ ク，これらすべての農薬を感度良く一斉に測定する ためには GC-MS で測定することが好ましい，PFB 化並びにメチル化した各農薬標準溶液の TICを Fig. 4，5 に示した.

$\mathrm{PFB}$ 化体の TIC では MCPA とジクロルプロッ プ及び $\mathrm{MCPB}$ と2,4,5-Tの保持時間が重なった がメチル化体では重ならなかった。また，両エス テル化体の検出感度を比較すると, メコプロップ, MCPA 及び2, 4-D では両エステル化体の間に差は なかったが，ジクロルプロップ，MCPBの PFB 化 体の感度はメチル化体に比べそれぞれ約 10 倍と約

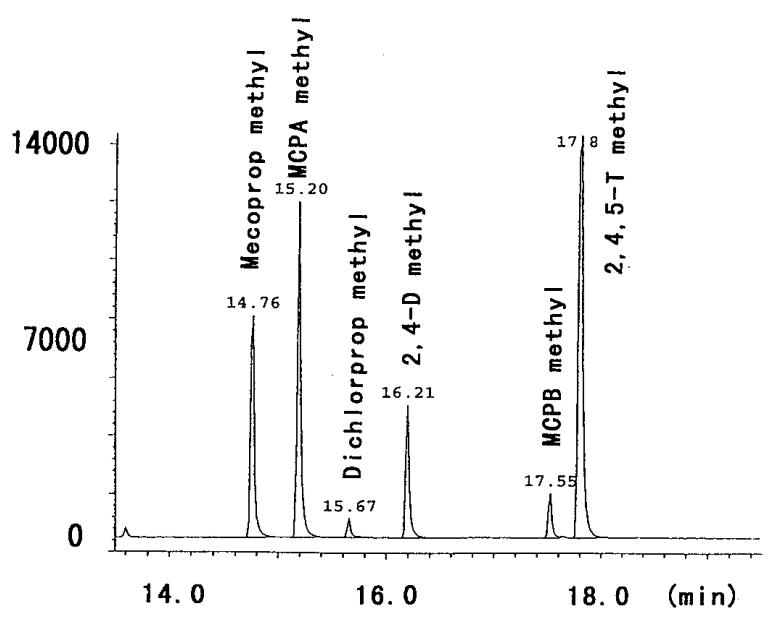

Fig. 5. TIC for Methyl Derivatives of Phenoxy Acid Herbicides (Mixture B: $5.0 \mu \mathrm{g} /$ $\mathrm{ml})$

Table 2. Mass Fragment Ions Formed from Derivatives of Phenoxy Acid Herbicides (Mixture B) by EI-GC-MS

\begin{tabular}{|c|c|c|c|c|c|c|c|c|}
\hline \multirow{2}{*}{$\begin{array}{l}\text { Pesticide } \\
\text { (mixture B) }\end{array}$} & \multicolumn{8}{|c|}{ Fragment ions } \\
\hline & \multicolumn{4}{|c|}{ PFB derivative } & \multicolumn{4}{|c|}{ Methyl derivative } \\
\hline Mecoprop & 169, & 268 & 394 & & 142 & 169 , & 228 , & 231 \\
\hline MCPA & 201 & 257 & $\overline{287}$ & $\underline{380}$ & 141 & 142 & 155 , & $\overline{214}$ \\
\hline Dichlorprop & 133, & 189, & 414 & & 162 & 164, & 189, & $\overline{249}$ \\
\hline $2,4-\mathrm{D}$ & 111, & 175, & $\overline{402}$ & & 199, & 175 & 234 , & $\overline{236}$ \\
\hline MCPB & 267 & 287 & $\overline{322}$ & $\underline{408}$ & 101, & 142, & 211 , & $\overline{242}$ \\
\hline $2,4,5-\mathrm{T}$ & 109, & 145 & 209 & $\overline{434}$ & 233 & 209 & 268 , & $\overline{270}$ \\
\hline
\end{tabular}

Underline means molecular ion. 
5 倍高かった.しかし，2,4,5-Tは逆に，メチル化体 の方が約 2 倍感度が高かった。

次に，エステル化した農薬の GC-MS (EI) による マススペクトルを测定し, 主なフラグメントイオン をTable 2 に示した。

$\mathrm{PFB}$ 化体のマススペクトルでは各農薬の分子量 にペンタフルオロベンジルの分子量 181 を加えた分 子イオンピークが得られた.また，メチル化体では， 各農薬の分子量にメチル基の分子量 14 を加之た分 子イオンピークが得られた。これらの結果から，各 分子イオンピークをモニターイオンとして SIM 法 で測定を行った.ただし, 2,4,5-Tのメチル化体は分 子イオンを用いて試料溶液を測定したとき食品由来 の妨害ピークと重なったため，妨害物と重ならない 基準ピークの $m / z 233$ をニターイオンとして用 いた.

SIM 法で測定したときのメチル化体の感度は PFB 化体の感度に比べ，ジクロルプロップでは約 1/2であったが, メコプロップ, MCPA, MCPB 及 び 2, 4, 5-T では約 5 倍高かった.また, 2, 4-D では約 2 倍高かった。

\section{3-3. エステル化条件の検討 フェノキシ酸系} $\mathrm{B}$ 農薬の PFB 化に要する臭化ペンタフルオロベン ジルのアセトン溶液濃度について検討した。すなわ ち，各農作物試料液に農薬を添加した後， 1，5， $10 \%$ PBF 試液を用いてエステル化を行い，それ ぞれの添加回収率を求めた。その結果を Fig. 6 に示 した。
$1 \% \mathrm{PBF}$ 試液ではアスパラガス，さといも及びと うもろこしの回収率は 32.0-59.2\%であり，玄米で は2.7-11.0\%であった５\%及び 10\% PBF 試液で はすべての農作物で $71.6 \%$ 以上の回収率が得られ た.このことから, PFB 試液は登録保留基準分析法 にある $1 \%$ では本法の場合不十分であり，5\%以上が 必要であると判明した。そこで，エステル化には 10\% PBF 試液を用いることとした. また，メチル化 はジアゾメタン試液を用いて常法によりエステル化 を行なった。

3-4. エステル化体のクリーンアップ $\mathrm{PFB}$ 化及びメチル化後の試験溶液を ECD-GCで測定し たところ，試料由来の妨害物質が多く認められたた めクリーンアップが必要であった. Sep-Pak ${ }^{\circledR} フ ロ$ リジルカートリッジにエステル化した各農薬標準品 の $n$-ヘキサン溶液を負荷し，5-30\% EA/H で溶出 して，各農薬の溶出パターンを調べた。

$\mathrm{PFB}$ 化体はカートリッジから負荷液である $n$-へ キサンによっても 30\%程度溶出され，20\% EA/H でほぼすべて溶出された。一方，メチル化体はへキ サン負荷液では溶出されず, $10 \% \mathrm{EA} / \mathrm{H}$ でほぼすべ て溶出された。この結果から，メチル化体はカート リッジに負荷後, $10 \% \mathrm{EA} / \mathrm{H}$ で溶出することにより クリーンアップできるが, PFB 化体はクリーンアッ プできないことが分った.したがって，フェノキシ 酸系 $\mathrm{B}$ 農薬についてはエステル化後クリーンアッ プすることなく，GC-MS (SIM) で直接測定するこ とを検討した。

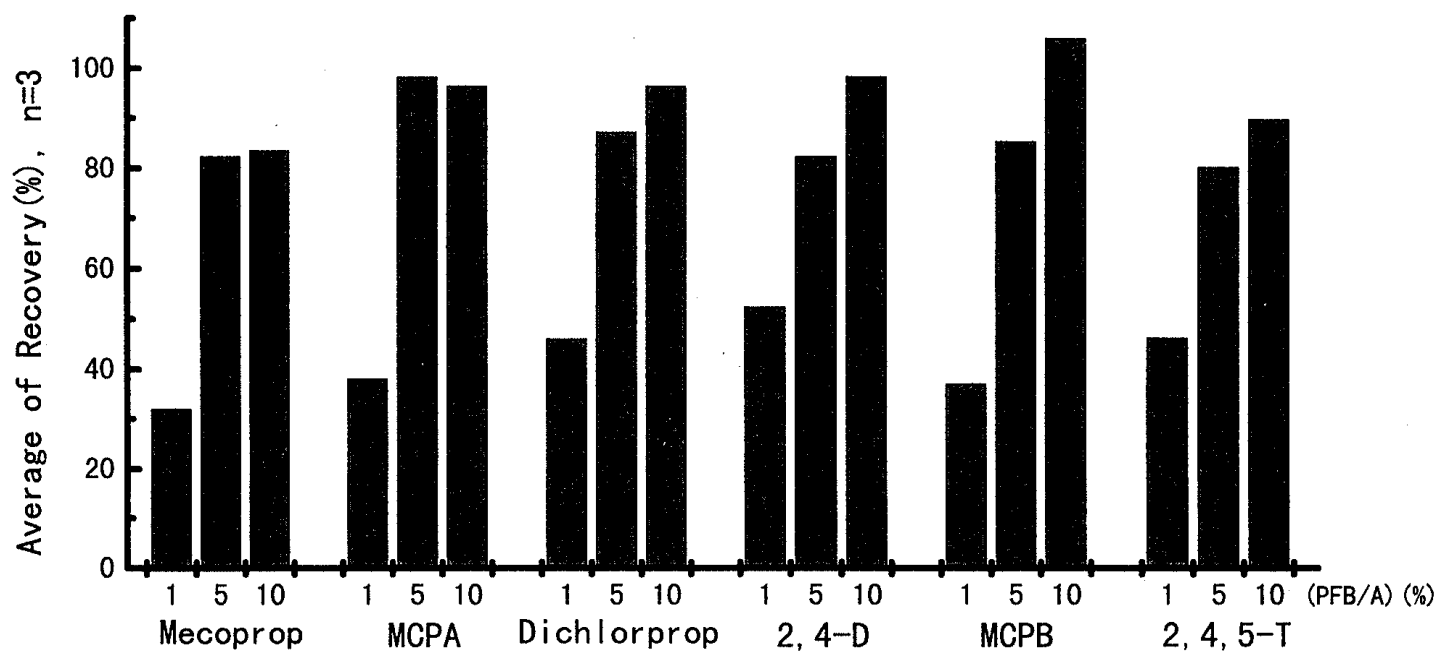

Fig. 6. Effect of Concentration of Pentafluorobenzylbromide on Recoveries of Phenoxy Acid Herbicides (Mixture B) from Asparagus

$\mathrm{PFB} / \mathrm{A}(\%)$ : Pentafluorobenzylbromide/Acetone (\%). Twenty five $\mu \mathrm{g}$ of phenoxy acid herbicides (mixture B) were spiked to $20 \mathrm{~g}$ of asparagus. 
3-5. GC-MS（SIM）による抽出液中農薬の測定 フェノキシ酸系 B 農薬を各農作物に添加して調製 した試料液を PFB 化またはメチル化した後, SIM で直接測定した。アスパラガスについてのマスクロ マトグラムを Fig. 7 及び 8 に示した。また各農作物 における添加回収率を Table 3 に示した。

アスパラガス試料液を PFB 化またはメチル化後 SIM で測定した結果，カートリッジでクリーンアッ プしなくても目的農薬のピークと試料由来の妨害 ピークは重ならず良好に測定することができた。ま た，さといも，玄米，とうもろこしについても SIM ではカートリッジでクリーンアップすることなく良 好に測定できることが分かった。

また Table 3 に示したように, PFB 化による添加
回収率は, 全ての農薬で $68.5 \%$ 以上であった。メチ ル化による添加回収率は玄米及びとうもろこしでは アスパラガス及びさといもに比べやや低い傾向に あったが，全ての農薬で $53.7 \%$ 以上であった。この 理由は PFB 化が加温 1 時間反応であるのに対して メチル化は室温放置反忘なので，試料液のエステル 化には PFB 化の方がより強力に作用するためと考 えられる。

\section{PFB 及びメチル化の比較}

上記の実験結果から, PFB 化及びメチル化の長所 及び短所について比較し，考察を行った。

4-1. エステル化の操作法 PFB 化では, $50^{\circ} \mathrm{C}$ の水浴中で 1 時間反応させる必要があったが，メ千 ル化の場合は室温 30 分放置でよかった. また, PFB

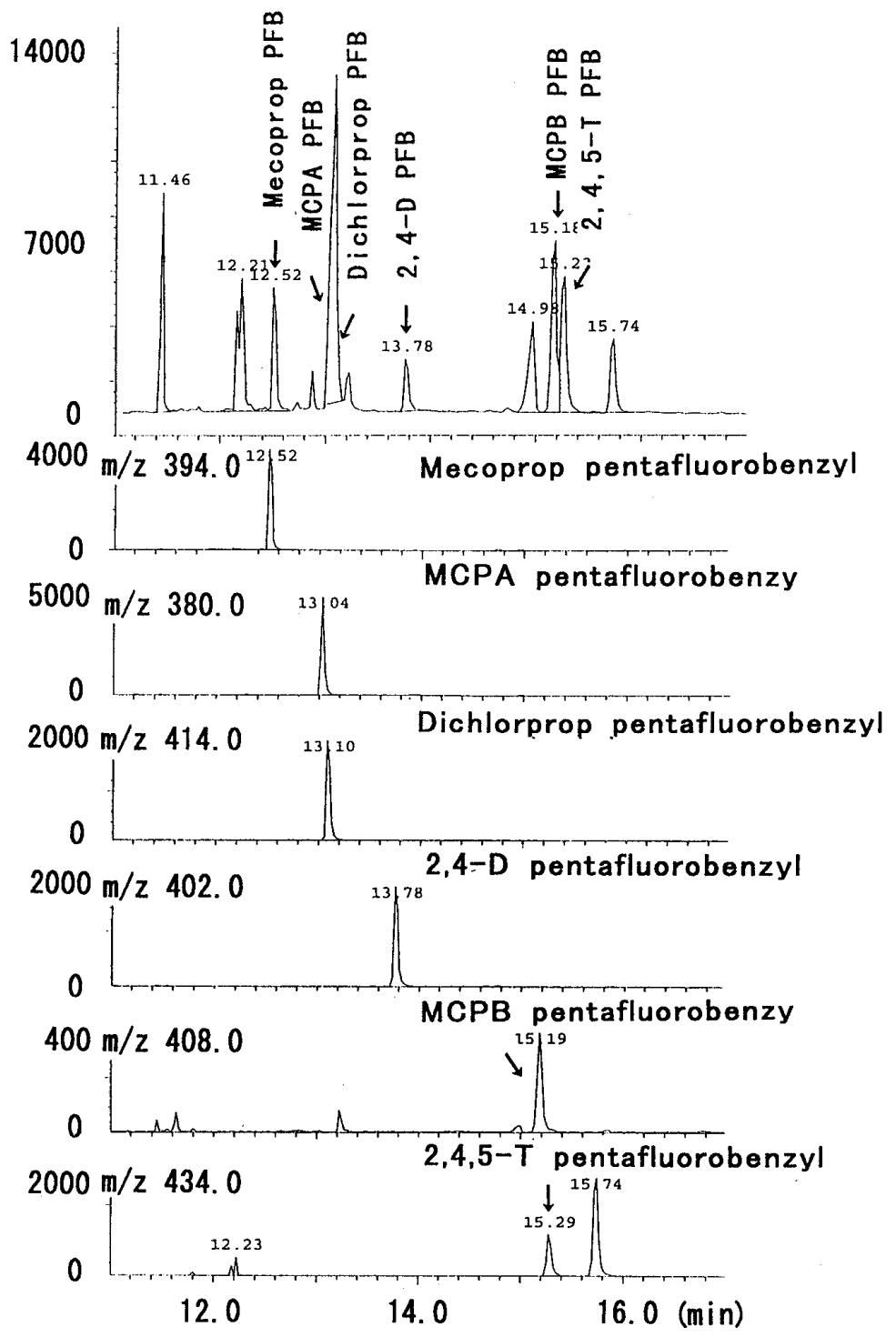

Fig. 7. TIC and Mass Chromatograms of Pentafluorobenzyl Derivatives (Mixture B) Extracted from Asparagus 


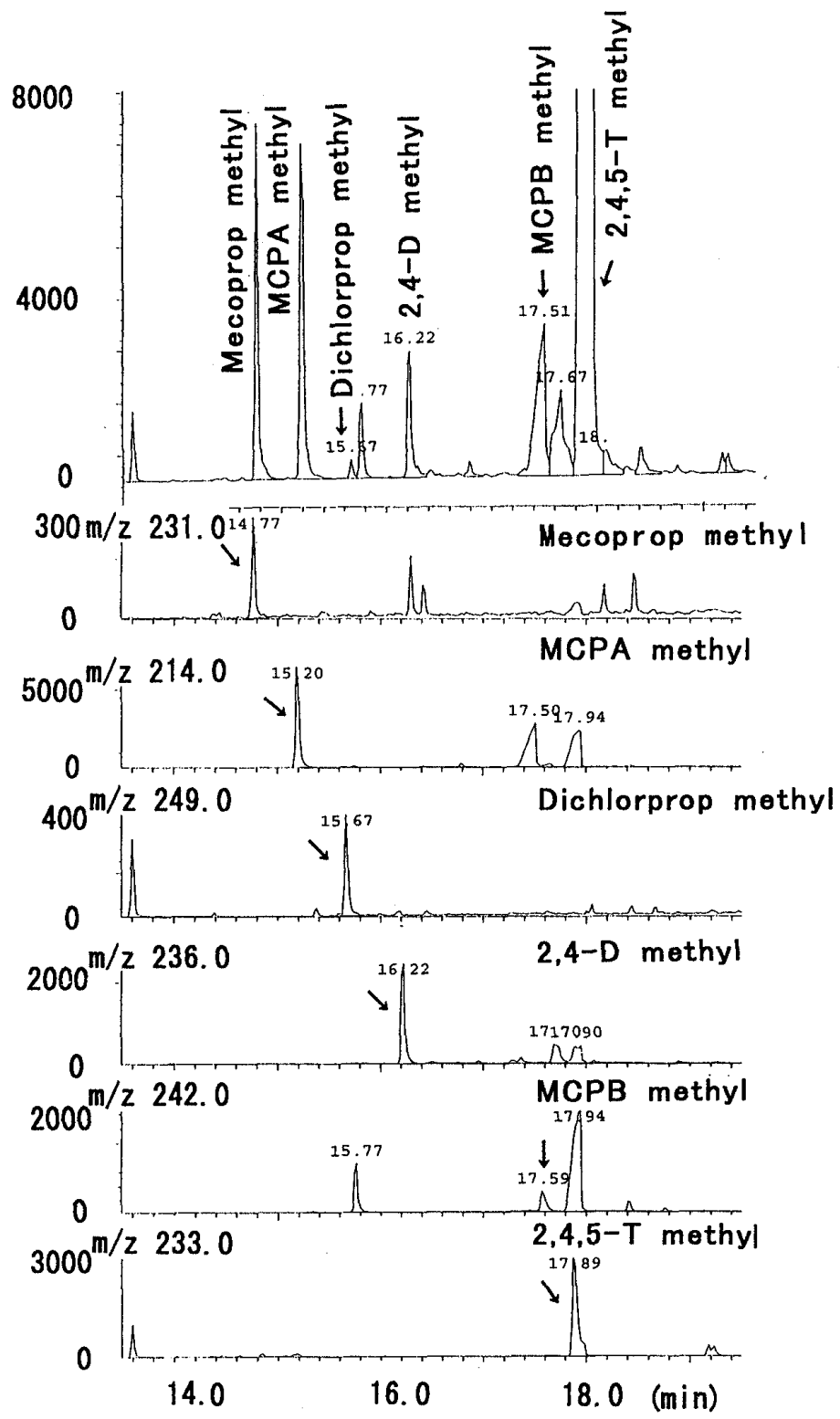

Fig. 8. TIC and Mass Chromatograms of Methyl Derivatives (Mixture B) Extracted from Asparagus

化後には $n$-ヘキサンに転溶する操作が必要であっ たが，メチル化の場合は必要なかったままた，PFB 化試薬の臭化ペンタフルオロベンジルは催滬性を有 し，メチル化試薬のジアゾメタン試液は有害性及び 爆発性があるために両者ともドラフト中で操作する 必要があった。

4-2. ECD-GCにおける感度ＰFB 化体では 対象とした 6 種類の農薬全てを検出することができ たが，メチル化体では MCPA，MCPB 及びメコプ ロップは検出できなかった。試薬ブランクピークは PFB 化ではメチル化に比べ多く認められ，PFB 化 では, $0.5 \mu \mathrm{g} / \mathrm{ml}$ 以下の農薬を ECD-GC で測定する のは困難であった。
4-3. GC-MS（SIM）における感度エステル 化後の各農薬の SIM 測定時の感度を比較した結果, MCPA，メコプロップ及び 2, 4-D の感度は PFB 化 体及びメチル化体間に差はなかったが，ジクロルプ ロップ，MCPBの PFB 化体はメチル化体に比べ, それぞれ約 10 倍と約 5 倍感度が高かった。しかし， 2, 4, 5-T は，メチル化体の方が約 2 倍高かった.

また，SIM で測定に用いたイオンはPFB 化体で は $m / z 380-430$ であり, メチル化体の $m / z$ 210-270に比べ大きかった.このことから, PFB化 体ではメチル化体に比べ他の農薬や試料由来の妨害 ピークと重なる可能性がより低かった。 
Table 3. Recoveries of Phenoxy Acid Herbicides (Mixture B) from Spiked Agricultural Products by GC-MS (SIM)

\begin{tabular}{llcccc}
\hline \hline \multirow{2}{*}{$\begin{array}{c}\text { Pesticide }_{\text {(mixture }}^{a)} \\
\text { (m) }\end{array}$} & Derivative & \multicolumn{4}{c}{ Recovery $(\%$, mean \pm S.D., $n=5)$} \\
\cline { 3 - 6 } & & Asparagus & Taro & Brown rice & Corn \\
\hline Mecoprop & PFB & $94.5 \pm 2.3$ & $91.7 \pm 2.4$ & $71.7 \pm 1.4$ & $82.7 \pm 2.7$ \\
& Methyl & $86.7 \pm 1.8$ & $88.1 \pm 1.2$ & $75.7 \pm 2.3$ & $78.1 \pm 2.2$ \\
MCPA & PFB & $92.2 \pm 2.4$ & $85.7 \pm 2.9$ & $92.5 \pm 1.3$ & $93.6 \pm 2.9$ \\
& Methyl & $69.5 \pm 3.2$ & $76.1 \pm 3.1$ & $69.4 \pm 2.8$ & $70.6 \pm 3.2$ \\
Dichlorprop & PFB & $95.0 \pm 1.2$ & $84.2 \pm 1.8$ & $86.1 \pm 2.3$ & $88.5 \pm 2.6$ \\
& Methyl & $66.2 \pm 2.1$ & $78.2 \pm 2.5$ & $66.8 \pm 2.8$ & $75.0 \pm 1.7$ \\
$2,4-D$ & PFB & $89.3 \pm 1.9$ & $83.4 \pm 3.4$ & $86.9 \pm 3.2$ & $90.1 \pm 3.0$ \\
\multirow{2}{*}{ MCPB } & Methyl & $60.6 \pm 2.3$ & $67.7 \pm 2.6$ & $56.9 \pm 2.4$ & $59.7 \pm 2.4$ \\
& PFB & $69.4 \pm 2.9$ & $68.5 \pm 1.9$ & $97.5 \pm 2.0$ & $98.5 \pm 1.2$ \\
$2,4,5-\mathrm{T}$ & Methyl & $58.9 \pm 1.5$ & $62.6 \pm 2.5$ & $54.7 \pm 3.1$ & $57.6 \pm 2.6$ \\
& PFB & $87.5 \pm 2.6$ & $80.0 \pm 2.9$ & $75.1 \pm 1.9$ & $69.1 \pm 1.4$ \\
& Methyl & $53.7 \pm 2.1$ & $60.9 \pm 1.8$ & $54.0 \pm 2.3$ & $53.7 \pm 1.9$ \\
\hline
\end{tabular}

a) Twenty five $\mu \mathrm{g}$ of phenoxy acid herbicides (mixture $\mathrm{B}$ ) were spiked to $20 \mathrm{~g}$ of each agricultural products.

\section{5. 残留実態調查}

オーストラリア産のアスパラガス, 中国産のさと いも及びU.S.A. 産の玄米, とうもろこしについて遊 離酸型及びエステル型フェノキシ酸系 9 種農薬を測 定した結果，これらの検体からはいずれの農薬も検 出されなかった。なお，本法による各農薬の検出限 界はエステル型フェノキシ酸系 A 農薬は ECD-GC で0.1 ppm，GC-MS（SIM）で0.05 ppm また遊離 酸型フェノキシ酸系 B 農薬の GC-MS（SIM）では $0.05 \mathrm{ppm}$ であった。

\section{ま と め}

1. 農作物中の遊離酸型及びエステル型フェノキ シ酸系 9 種除草剂の同時抽出並びに GC または GCMSによる一斉分析法を作成した。

2. 遊離酸型のエステル化法として $\mathrm{PFB}$ 化とメ チル化について比較検討した結果，操作性において はメチル化が，GC 及び GC-MSの感度においては
PFB 化が優れていた。

3. PFB 試液によるエステル化条件を検討した 結果，PFB 試液濃度は，登録保留基準の分析法にあ る1\%では本法の場合不十分で回収率が低く， 5-10\%が必要であった。

4. エステル型は試料液をクリーンアップ後 ECD-GC と GC-MS (SIM) で測定し，遊離酸型は工 ステル化後クリーンアップせずに GC-MS (SIM) で 測定した。いずれの方法でもアスパラガス，さとい も，玄米，とうもろこしについて，妨害物の影響な く測定することができた。

5. 4 種農作物に各農薬を $1.25 \mathrm{ppm}$ 添加したと きの本法による回収率は，エステル型は 50.8一-76.9\%, 遊離酸型は 53.7一-98.5\%であった。

謝辞本研究を行うにあたり種々ご協力いただ いた，横浜及び神戸検疫所輸入食品検疫・検査セン ターの諸氏に深謝致します。

\section{References}

1) Research Society for Countermeasure, of Environmental Integrity of Pesticides "Standard for Withholding Registration of Pesticides-Handbook for Standard of Residual Pesticides," Kagakukogyonippo Inc., Tokyo, 1995, pp.1085-1098.

2) Japanese Descendant Foundation (ed.), "Post-Harvest Application Pesticides-Surveillance Report for U.S.A.," Tokyo, 1989, p.122.

3) Suzuki T., Watanabe S., J. AOAC Int., 75, 720 (1992).

4) Butz S., Stan H.J., J. Chromatogr., 643, 227 (1993).

5) Balinova A., J. Chromatogr., 728, 319 (1996).

6) Sanchez-Brunete C., Garcia-Valcarcel A.I., Tadeo J.L., J. Chromatogr., 675, 213 (1994). 
7) Hajslova J., Tahtah W.H., Jehlickova Z., Kocourek V., Cuhra P., Sci. Total Environ., 132, 259 (1993).

8) Balinova A., J. Chromatogr., 643, 203 (1993).

9) Nouri B., Fouillet B., Toussaint G., Chambon P., Chambon R., Analyst, 120, 1133 (1995).

10) Gennaro M., Giacosa D., Baglietto C., Gennari M., Negre M., J. Liq. Chromatogr., 19, 911 (1996).

11) Edgell K.W., Feb E.J., Wesselman R.J., Longbottom J.E., J. AOAC Int., 76, 1098 (1993).

12) Albanis T.A., Hela D.G., J. Chromatogr., 707, 283 (1995).

13) Vink M., van der Poll J.M., J. Chromatogr., 733, 361 (1996).

14) Tsuchiya Y., Kogyo Yosui, 409, 50 (1992).

15) Ternes T.A., Baumann W., Nagel I.R., Fresenius, J. Anal. Chem., 354, 237 (1996).

16) Volmer D., Levsen K., Wuensch G., J. Chromatogr., 660, 231 (1994).

17) Crrescenzi C., Di C.A., Marchese S., Samperi R., Anal. Chem., 67, 1968 (1995).

18) Tonogai Y., Tsumura Y., Nakamura Y., Ito Y., Shokuhin Eiseigaku Zasshi, 33, 23 (1992).

19) Research Team for Analysis of Residual Pesticides (ed.), "New Residual Analytical Method for Pesticides," Chuohoki Public. Inc., Tokyo, 1995, pp.21, 248.

20) Research Team for Analysis of Residual Pesticides (ed.), "New Residual Analytical for Pesticides," Chuohoki Public. Inc., Tokyo, 1995, pp.396, 399.

21) Meeiring H.D., den Engelsman G., de Jong A.P.J.M., J. Chromatogr., 644, 357 (1993).

22) Lee A.S., Hong M.K., Smith A.E., J. AOAC Int., 78, 1459 (1995). 